\title{
Host-Directed Antivirals: A Realistic Alternative to Fight Zika Virus
}

\author{
Juan-Carlos Saiz *, Nereida Jiménez de Oya ${ }^{\circledR}$, Ana-Belén Blázquez ${ }^{\circledR}$, \\ Estela Escribano-Romero ${ }^{(D)}$ and Miguel A. Martín-Acebes * (D) \\ Department of Biotechnology, Instituto Nacional de Investigación y Tecnología Agraria y Alimentaria (INIA), \\ 28040 Madrid, Spain; jdeoya@inia.es (N.J.d.O.); blazquez@inia.es (A.-B.B.); eescribano@inia.es (E.E.-R.) \\ * Correspondence: jcsaiz@inia.es (J.-C.S.); martin.mangel@inia.es (M.A.M.-A.); Tel.: +34-91-347-1497 (J.-C.S.); \\ +34-91-347-8770 (M.A.M.-A.)
}

Received: 19 July 2018; Accepted: 22 August 2018; Published: 24 August 2018

\begin{abstract}
Zika virus (ZIKV), a mosquito-borne flavivirus, was an almost neglected pathogen until its introduction in the Americas in 2015, where it has been responsible for a threat to global health, causing a great social and sanitary alarm due to its increased virulence, rapid spread, and an association with severe neurological and ophthalmological complications. Currently, no specific antiviral therapy against ZIKV is available, and treatments are palliative and mainly directed toward the relief of symptoms, such as fever and rash, by administering antipyretics, anti-histamines, and fluids for dehydration. Nevertheless, lately, search for antivirals has been a major aim in ZIKV investigations. To do so, screening of libraries from different sources, testing of natural compounds, and repurposing of drugs with known antiviral activity have allowed the identification of several antiviral candidates directed to both viral (structural proteins and enzymes) and cellular elements. Here, we present an updated review of current knowledge about anti-ZIKV strategies, focusing on host-directed antivirals as a realistic alternative to combat ZIKV infection.
\end{abstract}

Keywords: flavivirus; Zika virus; therapy; host-directed antivirals

\section{Introduction}

Since the beginning of the 21st century, a number of infectious disease threats have emerged that demand a global response. Among them, severe acute respiratory syndrome virus, avian influenza in humans, pandemic influenza A (H1N1), Middle East respiratory syndrome coronavirus, chikungunya virus, and Ebola virus have been the most threatening ones. Nonetheless, the emergency of a vector-borne virus, Zika virus (ZIKV), which is responsible for congenital malformations and other neurological and ophthalmological disorders, was hard to predict.

ZIKV is a mosquito-borne virus belonging to the Spondweni serocomplex in the genus Flavivirus of the family Flaviviridae [1]. The virus has been isolated from various mosquito species, although it seems that the natural transmission vectors are mosquitoes of the genus Aedes [2,3]. Besides mosquito bites, viral direct human-to-human transmission can occur perinatally, sexually, and through breastfeeding and blood transfusion [4]. The ZIKV genome is a single-stranded RNA molecule $(\approx 10.7 \mathrm{~kb})$ of positive polarity encoding a single open reading frame (ORF) flanked by two untranslated regions at the $5^{\prime}$ and $3^{\prime}$ ends [5].

ZIKV was first isolated from the serum of a monkey in 1947, and one year later from Aedes africanus mosquitoes caught in the same area, the Zika forest [6]. Until it was detected in Asia in the 1980s, the virus had been confined to Africa. Later on, human outbreaks were reported in the Pacific islands, Micronesia in 2007 and, then, in French Polynesia in 2013 [4]. The natural course of ZIKV infection was usually asymptomatic or produce a relatively mild illness and an uneventful recovery [7], hence, the virus was considered an almost neglected pathogen until its recent introduction into the Americas in 2015, when it became a threat to global health, showing increased virulence, rapid spread, 
and an association with severe neurological complications such as an unexpected rise of microcephaly cases in fetuses and newborns and a remarkable increase in Guillain-Barré syndrome (GBS) cases [8]. This drove the World Health Organization (WHO) to declare a public health emergency of international concern (PHEIC) in 2016 [9].

ZIKV is a neurotropic virus with a wide tissue tropism [10-12], including reproductive tissues and organs. In males, ZIKV can infect testes, the prostate, and seminal vesicles [12,13], and in females it can infect the vagina, uterus, vaginal epithelium, uterine fibroblasts, Hofbauer cells, trophoblasts, and endothelial cells from the placenta [12,14]. ZIKV has also been detected in the cornea, neurosensory retina, optic nerve, aqueous humor, and tears [15]. Because of this, ZIKV infection can lead to severe neurological and ophthalmological disorders.

Lack of effective prophylactics, vaccines, or therapeutics hampers the fight against ZIKV. Consequently, inactivated viruses, live vector-based, and nucleic acid (DNA or RNA)-based candidates, subunit elements, virus-like particles, and recombinant viruses are been rehearsed, some of them already in clinical trials [16]. Likewise, many different compounds are being tested as possible therapeutic agents against ZIKV that target either viral or cellular components.

The present review discusses recent advances in the design and development of antivirals and therapeutics for ZIKV infection, focusing in those directed against host factors needed for the viral life cycle as a realistic alternative for the treatment of ZIKV infection.

\section{Therapeutic Approaches}

Since the recent outbreak in 2015 in the Americas, a quite high number of possible antiviral candidates are being tested in vitro and in vivo. However, until now, no specific therapy has been approved against any flavivirus [17], including ZIKV [18], and, thus, current treatments are mainly directed toward the relief of symptoms, such as fever and rash, by administering antipyretics, anti-histamines, and fluids for dehydration [15]. Nevertheless, it should be noted that some commonly used drugs, such as acetylsalicylic acid, are contraindicated in ZIKV-infected patients, since they increase the risk of internal bleeding, and other arboviruses (dengue or chikungunya viruses) that can co-infect the patients may produce hemorrhages [3].

Due to the natural course of ZIKV infection, which is usually asymptomatic or produce a relatively mild illness and an uneventful recovery, when facing anti-ZIKV strategies, a very important point to take into account is the main target population that would benefit from it, namely immunocompromised patients and pregnant women and their fetuses [4]. In this sense, only for some of the tested drugs their safety profiles are known [19]. However, in cases of Food and Drug Administration (FDA) (https: / / www.drugs.com/) category B compounds (animal reproduction studies have failed to demonstrate a risk to the fetus and there are no adequate and well-controlled studies in pregnant women), or even in those of category C (animal reproduction studies have shown an adverse effect on the fetus and there are no adequate and well-controlled studies in humans, but potential benefits may warrant use of the drug in pregnant women despite potential risks), or D (there is positive evidence of human fetal risk based on adverse reaction data from investigational or marketing experience or studies in humans, but potential benefits may warrant use of the drug in pregnant women despite potential risks), their use in pregnancy can be contemplated if the potential benefit outweighs the risks. Even more, some of the assayed compounds cross the placenta and, thus, can also benefit the fetus. Nonetheless, if used, this should be done in an individualized way, conditioning dosage and timings, and always under a clinician's control where the patient is informed of the pros and cons.

Current search for ZIKV antivirals is being conducted with different approaches: by screening of compounds libraries; by the repurposing of drugs of known active efficacy against other diseases now in use in clinical practice, many of which display broad-spectrum activity; and by testing natural products. Two different strategies can be applied when pursuing for antivirals, those searching for compounds directed to viral targets (direct-acting antivirals) and those aimed to target cellular components needed for the viral life cycle (host-directed antivirals). 


\section{Direct-Acting Antivirals}

Among the virus-directed drugs tested $[18,20]$ are those acting against the viral RNA-dependent RNA polymerase (non-structural protein 5 (NS5)) catalytic domain, including nucleoside analogs and polymerase inhibitors; the methyltransferase catalytic domain of the NS5 responsible for transferring the mRNA cap; the NS2B-NS3 trypsin-like serine protease needed for proper processing of the viral polyprotein; and the NS3 helicase. The crystal structures of all these proteins have already been resolved and will certainly help to find new antivirals [21-32]. In the same way, structures from other viral proteins are also available that could help to design ZIKV therapeutic alternatives, such as those of the capsid C protein [33], whose destabilization may impair ZIKV multiplication, the NS1 [34,35], an immuno-modulator, or the envelope glycoprotein [36-38], which mediates cell binding and endosomal fusion, constitutes a major target for neutralizing antibodies, and could be also the target for virucidal compounds [39].

On the other hand, it has also been reported that passive transfer of neutralizing antibodies to pregnant mice suppresses ZIKV multiplication, inhibits cell death, reduces the number of progenitor neuronal cells, and prevents microcephaly $[40,41]$. Likewise, administration of monoclonal antibodies (MAbs) recognizing the domain III of the ZIKV-E protein protect mice of lethal ZIKV challenge [42,43] and other MAbs are able to bind and neutralize ZIKV, including those directed against the E dimer epitope [44]. Human polyclonal antibodies produced in transchromosomal bovines also protect mice from ZIKV lethal infection, eliminated ZIKV induced tissue damage in the brain and testes, and protected against testicular atrophy [45]. Thus, administration of therapeutic antibodies seems to also be a potential strategy against ZIKV. Nevertheless, it should be noted that, although still controvertial in the case of ZIKV infection [46], the well-known antibody dependent enhancement effect (ADE) [47], of which dengue virus (DENV) is the prototypic model, may potentiate the risk of disease exacerbation.

\section{Host-Acting Antivirals}

Flaviviruses have small RNA genomes (around $10.7 \mathrm{~kb}$ in length) and thus require many host factors and co-option of cellular metabolic pathways to successfully infect host cells and propagate efficiently [48]. This offers an opportunity to search for host targets as therapeutic tools that, in many instances, as they are shared by different members of the Flaviviridae family, can be envisaged as pan-flaviviral antivirals [48-50]. This strategy can be directed to host factors implicated in infection, pathogenesis, and in the immune response, as it has been shown for DENV and the West Nile virus (WNV) [51]. In addition, their effect would be less prone to the emergence of mutants that will escape their action, as often occurs with drugs targeting viral components. Consequently, this kind of approach could ideally lead to the discovery of broad spectrum antivirals that could provide low cost but effective tools for the control of flaviviral threats.

Different approaches are being used to identify potential host factors as therapeutic targets against flaviviruses including the analyses of transcript levels (e.g., next generation RNA sequencing) for altered expression patterns during infection, proteome changes, kinases activities variations, and protein-RNA interactions (e.g., two-hybrid screenings and affinity chromatography). Likewise, functional analysis can be applied by overexpressing cDNAs or by RNAi-mediated loss of function screens using dsRNA, siRNA, or shRNA libraries, although it should be noted that in some cases downregulation is inefficient and some genes have redundant functions [51]. Replicons may also be used to specifically assay replication activity [52,53].

Theoretically, host-acting antivirals can be directed to any molecule or pathway implicated in the different steps of the viral life cycle, from early events (binding, entry, and fusion), to the formation of the replication complex, and the viral maturation and egress. 


\subsection{Early Steps: Binding, Entry, and Endosomal Fusion}

The first step of ZIKV infection is its binding to the cellular receptor (Figure 1). Several molecules have been proposed as a ZIKV receptor (members of the Tyro3/Axl/Mer (TAM) family of receptor tyrosine kinases, T-cell immunoglobulin and mucin domain (TIM) and dendritic cell-specific intercellular adhesion molecule 3-grabbing nonintegrin (DC-SIGN)) that are expressed in different neuronal and non-neuronal permissive cell types. These molecules are also receptors for other viruses, including flaviviruses such as DENV and WNV, regulate several cellular activities (adhesion, migration, proliferation, and survival, release of inflammatory cytokines, antigen uptake, and signaling), and play important roles in the host's response to infection [54]. However, elimination of a known receptor does not necessarily result in complete protection from viral infection, since flaviviruses use different receptors and, thus, there is always redundancy and alternatives. For instances, inhibiting, downregulating, knocking-down, or ablating AXL, although in some cases they reduce ZIKV infection, they do not completely abolish it, pointing to the use of different cell surface receptors on different cell types [55-58].

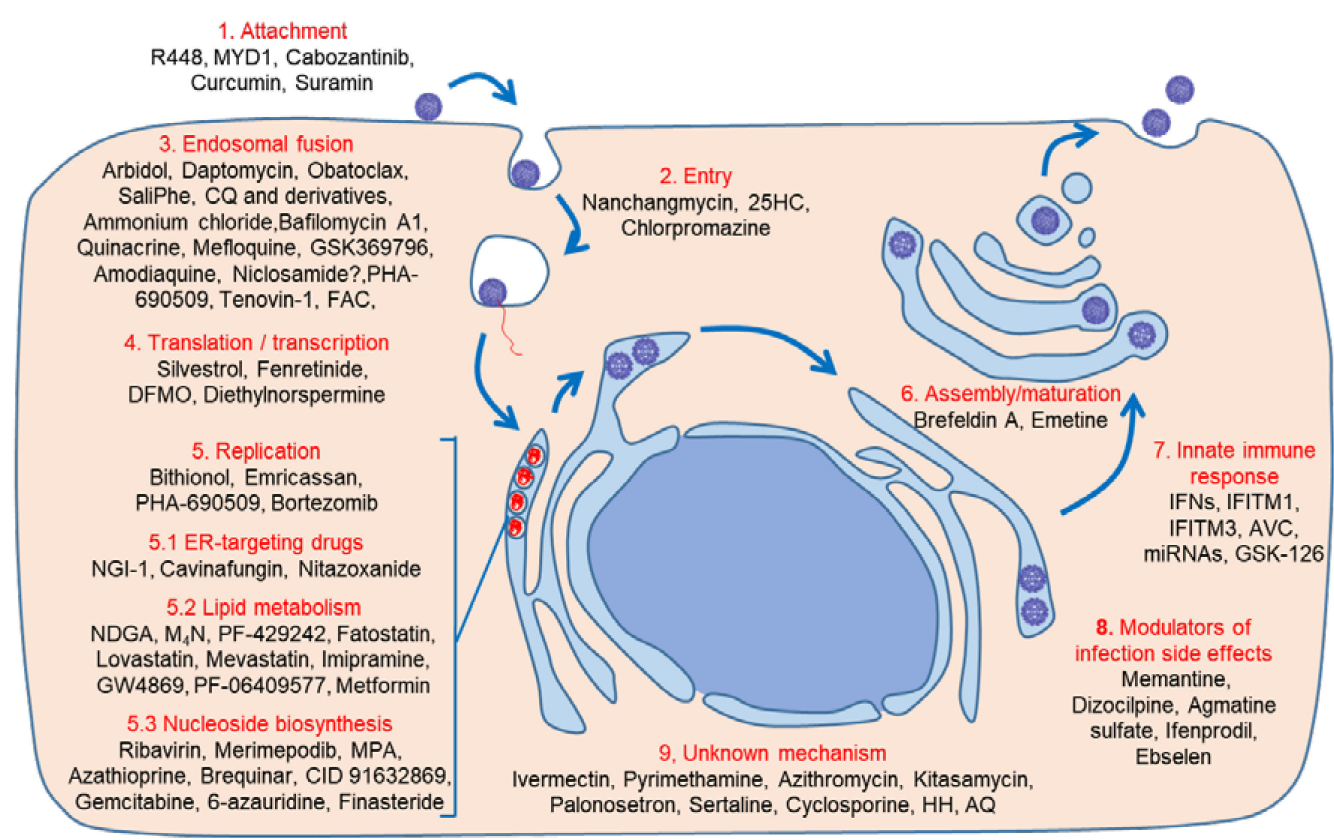

Figure 1. Life cycle of Zika virus (ZIKV) and drugs targeting cellular components. Drugs targeting: attachment (1); entry (2); endosomal fusion (3); translation/transcription (4); replication (5) by affecting the endoplasmic reticulum (ER) (5.1), the lipid metabolism (5.2), the pyrimidine and the purine biosynthesis (5.3); assembly or maturation of the virions (6); or innate immune response (7). Drugs effective for ZIKV infection side effects (8). Drugs with unknown mechanism (9). MYD1: AXL decoy receptor; 25HC: 25-hydroxycholesterol; CQ: chloroquine; FAC: iron salt ferric ammonium citrate; DFMO: difluoromethylornithine; NGI-1: N-linked Glycosylation Inhibitor-1; NDGA: nordihydroguaiaretic acid; $\mathrm{M}_{4} \mathrm{~N}$ : terameprocol; MPA: mycophenolic acid; IFNs: interferons; IFITM: interferon-induced transmembrane proteins; AVC: (1-(2-fluorophenyl)-2-(5-isopropyl-1,3,4-thiadiazol2-yl)-1,2-ihydrochromeno[2,3-c]pyrrole-3,9-dione; HH: hippeastrine hydrobromide; AQ: amodiaquine dihydrochloride dehydrate.

\subsubsection{Binding/Entry}

Different molecules have been shown to inhibit ZIKV infection at the entry step (Figure 1). R448 (an AXL kinase inhibitor) and MYD1 (an AXL decoy receptor) compromises, but do not completely abolish, ZIKV infection of glial cells [57]. R448, as well as cabozantinib, an inhibitor of AXL phosphorylation, that are currently in clinical trials for anticancer activities, significantly impairs ZIKV infection of human endothelial cells in a dose-dependent manner by affecting a post-binding 
step [59]. Likewise, curcumin, a widely used food additive and herbal supplement, reduces ZIKV infection in cell culture inhibiting cell binding while maintaining viral RNA integrity [60], as does suramin, an anti-parasitic that interferes with attachment to host cells and with virion biogenesis by affecting glycosylation and maturation [61,62].

\subsubsection{Endosomal Fusion}

Once ZIKV binds to the cell receptor, like other flaviviruses, it is internalized through clathrin-mediated endocytosis and transported to the endosomes with the involvement of cellular actin and microtubules to establish a productive infection (Figure 1) [57]. After internalization, to start translation and replication, the viral genome is released inside the cytoplasm by fusing the viral envelope with the membranes of the cellular endosomes, a process triggered by acidic pH inside them [63,64]. Nanchangmycin, an insecticide and antibacterial polyether, inhibits ZIKV multiplication and, although the exact mechanism of action has not been completely elucidated, it probably targets AXL and blocks clathrin-mediated endocytosis [65]. Acid endosomal pH triggers rapid conformational changes on viral envelope protein that result in its fusion with endosomal membrane in a $\mathrm{pH}$-dependent manner, thus allowing nucleocapsid release to the cytoplasm for genome uncoating (Figure 1). The optimal pH for conformational rearrangements and viral fusion is 6.3-6.4, and these processes are likely dependent on the presence of cholesterol and specific lipids in the target membrane [66]. These processes can be potentially druggable, and in fact, arbidol, a broad-spectrum antiviral and immunomodulatory use for human influenza A and B infections, inhibits ZIKV multiplication in cell culture probably because it intercalates into membrane lipids leading to the inhibition of membrane fusion between virus particles and plasma membranes, and between virus particles and the membranes of endosomes [67]. Chlorpromazine, an antipsychotic drug that also inhibits clathrin-mediated endocytosis, reduced ZIKV infection, confirming the requirement for clathrin-mediated endocytosis of ZIKV [68]. In addition, 25-hydroxycholesterol (25HC) is increased in ZIKV-infected human embryonic cells and brain organoids, and reduces viremia and viral loads without affecting viral binding, but blocking internalization and suppressing viral and cell membranes fusion [69]. Even more, 25HC reduces mortality and prevents microcephaly in ZIKV-infected mice, and also decreases viral loads in the urine and serum of treated non-human infected primates [69]. Daptomycin, a lipopeptide antibiotic that inserts into cell membranes rich in phosphatidylglycerol, which suggests an effect on late endosomal membranes enriched in this lipid, has also been described as a ZIKV inhibitor [70].

The dependence on endosomal acidification for ZIKV infection also provides a host target suitable for antiviral intervention. For instance, Obatoclax (or GX15-070), an anti-neoplastic and pro-apoptotic inhibitor of the Bcl-2 that targets cellular Mcl-1, impairs ZIKV endocytic uptake by reducing the $\mathrm{pH}$ of the endosomal vesicles in cell culture, and thereby most likely inhibits viral fusion [71,72]. However, Obatoclax, which presents a low solubility, has not produced satisfactory results in clinical trials for hematological and myeloid diseases. Saliphenylhalamide (SaliPhe), which targets vacuolar adenosine triphosphatase enzyme (ATPase) and blocks the acidification of endosomes, inhibits ZIKV multiplication in human retinal pigment epithelial cells [71] that are natural targets for ZIKV infection [12]. Similar results were found by Adcock et al. (2017) with SaliPhe using a different screening [73]; however, they reported that, contrary to that described by others [65], other compounds that interfere with the endocytic pathway, such as dynasore, that blocks clathrin-mediated endocytosis, or monensin, a cation transporter, were either toxic for the cells used or did not show any anti-ZIKV activity, as neither did chloroquine (CQ). These contradictory results are probably explained by the different methodologies, cell types, and, to a lower extent, viral strains used to analyze the antiviral activities of the compounds and suggest that compounds showing different activities should be carefully evaluated before going further with investigations. In this line, and contrary to above mentioned report [73], CQ, an FDA-approved anti-inflammatory 4-aminoquinoline and an autophagy inhibitor widely used as an anti-malaria drug that is administered to pregnant women at risk of 
exposure to Plasmodium parasites, was shown to have anti-ZIKV activity in different cell types (Vero cells, human brain microvascular endothelial cells (hBMECs), and human neural stem cells (NSCs)), affecting early stages of the viral life cycle, possibly by raising the endosomal $\mathrm{pH}$ and inhibiting the fusion of the envelope protein to the endosomal membrane [74,75]. CQ has been shown to reduce placental and fetal ZIKV infection [76], and also attenuate ZIKV-associated morbidity and mortality in mice and protect the fetus from microcephaly [77]. Even more, CQ attenuated vertical transmission in ZIKV-infected pregnant interferon signaling-competent Swiss Jim Lambert (SJL) mice, significantly reducing fetal brain viral loads [78]. Similarly, CQ, and other lysosomotropic agents (ammonium chloride, bafilomycin A1, quinacrine, mefloquine, and $N$-tert-Butyl Isoquine (GSK369796)) that neutralize the acidic $\mathrm{pH}$ of endosomal compartments, block infection of a human fibroblast cell line and Vero cells [68,75].

Additionally, by medicinal chemistry-driven approaches, a series of new 2,8-bis(trifluoromethyl)quinoline and $N$-(2-(arylmethylimino)ethyl)-7-chloroquinolin-4-amine derivatives have been proved to inhibit ZIKV replication in vitro with a higher potency than chloroquine or mefloquine $[79,80]$. More recently, by screening FDA-approved drugs using a cell-based assay, it has been shown that amodiaquine, another antimalarial drug, also has anti-ZIKV activity in cell culture by targeting early events of the viral replication cycle [81]. Niclosamide, a category B antihelmintic drug approved by FDA, was capable of inhibiting ZIKV infection, and although its antiflaviviral effect has been associated to its ability to neutralize endolysosomal $\mathrm{pH}$ and interfere with $\mathrm{pH}$-dependent membrane fusion, in the case of ZIKV, it seems that it was affecting other post-entry steps [82]. In addition, recently, it has been reported that niclosamide decreases ZIKV production, partially restores differentiation, and prevents apoptosis in human induced NSCs; even more, it can partially rescue ZIKV-induced microcephaly and attenuate infection in a developed humanized ZIKV-infected embryo model in vivo [83]. Likewise, tenovin-1, which represses cell growth and induces apoptosis in cells expressing p53 by inhibiting the protein-deacetylating activities of SirT1 and SirT2 and, thus, affects endosome functions, potently inhibits ZIKV infection in primary placental fibroblast cells [65]. Iron salt ferric ammonium citrate (FAC) also inhibits ZIKV infection through inducing viral fusion and blocking endosomal viral release by promoting liposome aggregation and intracellular vesicle fusion [84]. Overall, these studies evidence the potential of targeting viral entry to combat ZIKV.

\subsection{Translation/Transcription}

Once ZIKV-RNA is released from the endosomes in the cytoplasm, it acts as mRNA to synthesize the negative-strand viral RNA that directs positive-strand RNA synthesis (Figure 1) [4]. Silvestrol, a natural compound isolated from the plant Aglaia foveolata that it is known to inhibit the Asp-Glu-Ala-Asp (DEAD)-box RNA helicase eukaryotic initiation factor-4A (eIF4A) required to unwind structured $5^{\prime}$-untranslated regions and thus impairing RNA translation, exerts a significant inhibition of ZIKV replication in A549 cells and primary human hepatocytes [85]. N-(4-hydroxyphenyl) retinamide (fenretinide or 4-HPR), an activator of retinoid receptors that inhibits the proliferation of cancer cells and can induce apoptosis, inhibits ZIKV in cell culture and significantly reduces both serum viremia and brain viral burden in mice by decreasing the rate of viral RNA synthesis, though not via direct inhibition of the activity of the viral replicase [86]. ZIKV relies on polyamines for both translation and transcription [87], so that, drugs targeting the polyamine biosynthetic pathway, such as difluoromethylornithine (DFMO or eflornithine), an FDA-approved drug that is used to treat trypanosomiasis, hirsutism, and some cancers, as well as diethylnorspermine (DENSpm) limit viral replication in BHK-21 cells [88].

\subsection{Replication, Assembly, and Maturation}

ZIKV replication and particle morphogenesis take place associated with a virus-induced organelle-like structure derived from the membrane of the endoplasmic reticulum (ER) (Figure 1) [4]. De novo synthesized positive strand-RNA, once packaged, form enveloped immature virions in the ER, 
enter the secretory pathway and, then, in the trans-Golgi network, the prM is cleaved before the virus is released from the infected cell (Figure 1) [89,90].

ER-membrane multiprotein complexes, such as the oligosaccharyltransferase (OST) complex, have been reported to be critical host factors for flavivirus multiplication. In this regard, it has been shown that the N-linked Glycosylation Inhibitor-1 (NGI-1) chemical modulator of the OST complex blocks ZIKV-RNA replication in different cell types [91]. Similarly, the host ER-associated signal peptidase (SPase) is an essential, membrane-bound serine protease complex involved in cleavage of the signal peptides of newly synthesized secretory and membrane proteins at the ER and also for processing of the flavivirus prM and E structural proteins [92]. It has also been reported that cavinafungin, an alaninal-containing lipopeptide of fungal origin, potently inhibits growth of ZIKV-infected cells [93]. Nitazoxanide, a broad-spectrum antiviral agent approved by the FDA as an antiprotozoan and with potential activity against several viruses in clinical trials (rotavirus and norovirus gastroenteritis, chronic hepatitis $\mathrm{B}$, chronic hepatitis $\mathrm{C}$, and influenza), also inhibits virus infection targeting a post-attachment step, most likely virus genome replication [94]. Likewise, Brefeldin A, a Penicillium sp. product that inhibits protein transport from the ER to the Golgi apparatus, inhibits ZIKV multiplication [95], as does Emetine, an anti-protozoal agent that inhibits both ZIKV NS5 polymerase activity and disrupts lysosomal function [96].

ZIKV infection leads to cell-death by inducing host caspase-3 and neuronal apoptosis during its propagation [97]. Thereby, bithionol, a caspase inhibitor, inhibits ZIKV strains of different geographical origin in Vero cells and human astrocytes [98]. Similarly, by using a drug repurposing screening of over 6000 molecules, it was found that emricasan, a pan-caspase inhibitor that restrains ZIKV-induced increases in caspase-3 activity and is currently in phase 2 clinical trials in chronic hepatitis $\mathrm{C}$ virus (HCV)-infected patients, protected human cortical neural progenitor cells (NPC) in both monolayer and three-dimensional organoid cultures, showing neuroprotective activity without suppression of viral replication [82]. Additionally, bortezomib, a dipeptide boronate proteasome inhibitor approved for treatment of multiple myeloma and mantle cell non-Hodgkin's lymphoma that regulates the Bcl-2 family of proteins, has also been described as a ZIKV inhibitor [70]. Similarly, different cyclin-dependent kinase (CDK) inhibitors, such as (alphaS)-4-(Acetylamino)-alpha-methyl-N-(5-(1-methylethyl)-2-thiazolyl)benzeneacetamide (PHA-690509), reduced ZIKV-infection and propagation [82]. However, CDK inhibitors should not be suitable for the treatment of pregnant women but could be useful for the treatment of other non-pregnant patients, preventing the complications associated with ZIKV infection.

\subsubsection{Lipid Metabolism Modulators}

The need for specific host lipids for flavivirus replication and particle envelopment make lipid metabolism a potential target for an antiviral search [66,99], and, even though manipulating a major metabolic pathway such as lipid biosynthesis can be envisaged as a dangerous antiviral approach due to the undesirable effects that could be detrimental for the host, current use of drugs such as ibuprofen and aspirin (cyclooxygenase-2 (COX-2) inhibitors) or statins (3-hidroxi-3-metil-glutaril-CoA (HMG-CoA) reductase inhibitors) highlights the feasibility of lipid-based therapeutics [100,101]. Accordingly, inhibition of key enzymes involved in fatty acid synthesis, such as acetyl-CoA carboxylase (ACC) [102], and fatty acid synthase (FASN) [103-105], are potential targets for anti-ZIKV therapy. In this line, we have reported that nordihydroguaiaretic acid (NDGA) and its derivative tetra-O-methyl nordihydroguaiaretic (M4N or terameprocol), two compounds that disturb the lipid metabolism probably by interfering with the sterol regulatory element-binding proteins (SREBP) pathway, inhibit the infection of ZIKV and WNV, likely by impairing viral replication, as did other structurally unrelated inhibitors of the SREBP pathway, such as 4-[(Diethylamino)methyl]- $N$-[2-(2-methoxyphenyl)ethyl]-N-(3R)-3-pyrrolidinyl-benzamide dihydrochloride (PF-429242) and fatostatin [106]. In the same way, the dependence on cholesterol for different processes during flavivirus infection also provides a suitable target for antiviral strategies. As mentioned above, 25HC reduces viremia and viral loads in vitro, and also reduces mortality and prevent microcephaly in mice, and decreases viral loads in the urine and serum in non-human infected 
primates [69]. Lovastatin and mevastatin are hypolipidemic agents (HMG-CoA inhibitors) belonging to the family of statins that are widely used for lowering cholesterol in patients with hypercholesterolemia and have been previously shown to present antiviral activity against dengue and hepatitis $C$ viruses. Both agents have been proposed as therapeutic candidates against ZIKV [107]. In fact, lovastatin attenuates nervous injury in animal models of GBS [108]. Likewise, imipramine, an FDA-approved antidepressant, inhibits ZIKV-RNA replication and virion production in human skin fibroblasts, probably by interfering with intracellular cholesterol transport [109]. Regarding sphingolipid metabolism, which has been involved in flavivirus infection [66], treatment with the neutral sphingomyelinase inhibitor GW4869 reduced ZIKV production by affecting viral morphogenesis [110] as described for other flaviviruses [111]. Finally, since adenosine monophosphate-activated protein kinase (AMPK) is a master regulator of lipid metabolism, its activation by PF-06409577 or metformin reduced ZIKV infection by impairing viral replication [112,113]. Thus, targeting lipid metabolism could provide therapeutic alternatives for the discovery of host-directed antivirals against ZIKV.

\subsubsection{Nucleosides Biosynthesis Inhibitors}

The NS5 protein is the viral RNA-dependent RNA polymerase responsible for the RNA synthesis that also inhibits interferon (IFN) signaling by acting over the signal transducer and activator of transcription 2 (STAT2) protein [114], being, thus, a major target for antiviral design. Besides the proven antiviral activities of different nucleosides analogs and inhibitors of the ZIKV-NS5 [18], several inhibitors of the biosynthesis of nucleosides (purines and pyrimidines) also impair ZIKV replication (Figure 1). Ribavirin is an inhibitor of the inosine monophosphate dehydrogenase (IMPDH) with antiviral activity to several RNA viruses [115], but its mechanism of action is not entirely clear. It may act as a guanosine synthesis inhibitor, a viral cap synthesis inhibitor, a viral RNA mutagen, and as an inducer of lethal mutagenesis [116-118]. By using a cell-based assay, no antiviral activity of the drug was initially observed [73] but, later on, it was reported that although no activity against ZIKV was detected in Vero cells, the drug did inhibit virus multiplication in human cell lines, including liver Huh-7 and rhabdomyosarcoma (RD) cells [119]. Further studies have confirmed an inhibitory activity of ribavirin against ZIKV strains of different geographical origin in various types of cells, such as human neural progenitor cells (hNPCs), human dermal fibroblasts (HDFs), human lung adenocarcinoma cells (A549), and even in Vero cells [120-122]. Still more, the drug was shown to abrogate viremia in ZIKV-infected STAT-1-deficient mice [121], which lack type I IFN signaling, are highly sensitive to ZIKV infection, and exhibit a lethal outcome. Two other inhibitors of IMPDH, merimepodib (MMPD or VX-497) [123] and mycophenolic acid (MPA) [65,70,124] also inhibit ZIKV-RNA replication in different cell types, including Huh-7 cells, human cervical placental cells, and neural stem and primary amnion cells. However, other authors [73] have described that MPA have little effect on ZIKV replication and showed significant cell toxicity. Likewise, azathioprine, another inhibitor of purine synthesis and immunosuppressant, impaired ZIKV replication in HeLa and JEG3 cells [70]; nonetheless, its use in pregnant women is not recommended. The above described contradictory results stress again the differences that drug treatments may have as a consequence of the different viral strains, cell types, and methodologies used to assess them.

As with the inhibitors of purine biosynthesis, compounds inhibiting the synthesis of pyrimidines have also effect on ZIKV replication (Figure 1). So that, the virus was highly susceptible to brequinar and CID 91632869 treatments in cell culture [73]. However, it should be noted that it has been reported that brequinar, as well as DD264, antiviral activity may not be due to pyrimidine deprivation, but rather to the induction of the cellular immune response $[125,126]$. Similarly, other inhibitors of the pyrimidine synthesis, such as gemcitabine, an activator of cellular caspases [65,71], and, although with a lower efficiency probably due to its lower solubility, 6-azauridine and finasteride, a 4-azasteroid analog of testosterone that inhibit type II and type III $5 \alpha$-reductase and is being tested for benign prostatic hyperplasia and male pattern baldness, reduce ZIKV replication [73,107]. 


\subsubsection{Unknown Mechanisms}

Several other compounds have been shown to have anti-ZIKV activity by inhibiting viral entry and/or RNA synthesis, although their mechanisms of action have not yet been fully elucidated. Among them are antiparasitics such as ivermectin (used mainly against worms infections) and pyrimethamine (a folic acid antagonist that inhibits the dihydrofolate reductase and, thus, DNA and RNA synthesis, is classified as a pregnancy category $\mathrm{C}$, and was initially used to treat malaria and now toxoplasmosis and cystoisosporiasis) [70]; antibiotics such as azithromycin that prevents infection, replication, and virus-mediated cell dead [55], and kitasamycin (a natural product from Streptomyces narbonensis that inhibits protein biosynthesis) [107]; drugs used to prevent chemotherapy-induced nausea and vomiting as palonosetron (a FDA-approved 5-HT3 antagonist) [107]; antidepressants like sertraline (a selective serotonin reuptake inhibitor) [107] and cyclosporine (that is also use for rheumatoid arthritis, psoriasis, Crohn's disease, nephrotic syndrome, and in organ transplants, is believed to lower the activity of T-cells, and is currently in clinical trials for tis possible use in ameliorate neuronal cellular damage) [70]. Similarly, after chemical screening, it was found that hippeastrine hydrobromide $(\mathrm{HH})$, an active component of traditional Chinese medicine, and amodiaquine dihydrochloride dihydrate (AQ), an FDA-approved drug for treatment of malaria, inhibit ZIKV infection of human pluripotent stem cell-derived cortical NPCs and in adult mouse brain in vivo even when the infection was already ongoing but, again, their mechanisms of action are not known [127].

\section{Drugs Preventing ZIKV Infection Side Effects}

Besides drugs that act against host targets directly implicated in the viral cycle, there are compounds that can prevent undesirable effects of ZIKV infection. In this regard, ZIKV infection leads to massive neuronal damage, especially of neural progenitor cells, and neurodegeneration [128-130], via both direct replication in neuronal cells and possibly through increased excitotoxicity via over activation of $N$-methyl-D-aspartate receptor (NMDAR)-dependent neuronal excitotoxicity in nearby cells. Memantine, a pregnancy category B FDA-approved drug widely used to treat patients with Alzheimer's disease, as well as other NMDAR blockers (dizocilpine, agmatine sulfate, or ifenprodil), prevents neuronal damage and death and intraocular pressure increase induced by ZIKV infection in infected mice, but it does not affect virus replication, pointing to its possible use to prevent or minimize ZIKV-related microcephaly during pregnancy [131]. Ebselen (EBS), an antioxidant that reduces oxidative stress and improves histopathological features in a testicular injury study model and is currently in clinical trials for various diseases, showed minor effects in reducing ZIKV progeny production and viral E protein expression and on overall survival and viremia level of challenged AG129 mice; however, it should be noted that EBS reduced some ZIKV-induced effects, such as testicular oxidative stress, leucocyte infiltration, and production of pro-inflammatory response, whereas, in a model of male-to-female mouse sperm transfer, the drug improved testicular pathology and prevented the sexual transmission of ZIKV [132].

\section{Innate Immunity Modulation}

IFNs play a key role in the elimination of pathogens and they are release upon the activation of the innate immune response by infecting viruses. In this way, ZIKV infection induces IFN signaling pathways and further activates cytoplasmic retinoic acid inducible gene 1 protein (RIG1)-like receptors (RLRs) and several type I and III IFN-stimulated genes, driving to the subsequent activation of the Janus kinase (JAK)/STAT innate immune pathway that confer resistance to ZIKV infection [54]. Different studies showed that IFN- $\alpha$, IFN- $\beta$, and IFN- $\gamma$ inhibit ZIKV replication in cell culture $[124,133,134]$, and that treatment of pregnant mice with IFN- $\lambda$ reduced ZIKV infection [135]. In addition, IFITM1 and IFITM3, which are interferon-induced transmembrane proteins, impair early stages of ZIKV infection. Even more, IFITM3 prevents ZIKV-induced cell death [136]. Likewise, it has been reported that an interferon-activating small molecule 
(1-(2-fluorophenyl)-2-(5-isopropyl-1,3,4-thiadiazol-2-yl)-1,2-ihydrochromeno[2,3-c]pyrrole-3,9-dione (AVC) strongly inhibits replication of ZIKV in cell culture [137]. However, it is also known that the virus is capable of evading type I IFN responses by acting over the JAK/STAT signaling pathway [114,138-140], and that type I IFNs might be mediators of pregnancy complications, including spontaneous abortions and growth restriction [141]. In any case, use of IFN against ZIKV, alone or in combination with other antivirals, deserve further studies.

By screening a library of known human microRNAs (miRNAs), small, noncoding RNAs (sncRNAs) that modulate gene expression post-transcriptionally and regulate a broad range of cellular processes, several miRNAs were found to inhibit ZIKV by increasing the capability of infected cells to respond to infection through the interferon-based innate immune pathway [142]. Another alternative is intervening over epigenetic regulation by using epigenetics modulators. For instance, histone H3K27 methyltransferases (EZH1 and EZH2) suppress gene transcription and it has been shown that inhibitors such as 1-[(2S)-butan-2-yl]-N-[(4,6-dimethyl-2-oxo-1H-pyridin-3-yl)methyl]-3-methyl6-(6-piperazin-1-ylpyridin-3-yl)indole-4-carboxamide (GSK-126) reduce ZIKV multiplication in cell culture through the activation of cellular antiviral and immune responses [143]. In any case, further studies are needed to evaluate the potential therapeutic capability of these immunomodulators against ZIKV infection.

\section{Conclusions}

A great effort is being lately made to find compounds to fight ZIKV infection by applying different approaches, from repurposing of drugs with known antiviral activity to the screening of bioactive molecules from different libraries, as well as natural products. However, most of the already tested drugs have been found to inhibit viral replication in vitro, and only a few have been tested in vivo. Hence, since, in many instances, the results will be difficult to extrapolate to humans, it would be hard for most of the tested antivirals to complete the entire drug development pipeline. In addition, it should be remarked that many drugs could have untoward effects and, thus, careful evaluation should be conducted before using them in clinical practice, as the main target populations for anti-ZIKV therapy will be pregnant women and patients with other medical complications.

Many of the already tested drugs are directed against viral structural and enzymatic proteins, including, for instance, anticancer and anti-inflammatory molecules, antibiotics, and antiparasitics; however, it is well known that this approach can easily lead to the appearance of resistance. Since flaviviruses require many host factors and co-option of cellular metabolic pathways to successfully infect host cells and propagate efficiently, this offers an opportunity to search for host targets as therapeutic tools that, in many instances, can be broad spectrum agents, and which effect would be less prone to the emergence of mutants that will escape their action. Because of that, and even though manipulating host metabolic pathways can be seen as dangerous due to the undesirable effects that could be detrimental for the host, its success for other diseases make of them a realistic option for the treatment of ZIKV infection.

Funding: This study was funded by The Spanish Ministry of Economy and Competitiveness (MINECO) grant numbers RTA2015-00009 and E-RTA2017-00003-C02 (to J.-C.S.) and AGL2014-56518-JIN (to M.A.M.-A.).

Conflicts of Interest: The authors declare no conflict of interest. The funders had no role in in the writing of the manuscript or in the decision to publish.

\section{References}

1. Kuno, G.; Chang, G.J.; Tsuchiya, K.R.; Karabatsos, N.; Cropp, C.B. Phylogeny of the genus flavivirus. J. Virol. 1998, 72, 73-83. [PubMed]

2. Diagne, C.T.; Diallo, D.; Faye, O.; Ba, Y.; Gaye, A.; Dia, I.; Weaver, S.C.; Sall, A.A.; Diallo, M. Potential of selected senegalese Aedes spp. Mosquitoes (Diptera: Culicidae) to transmit Zika virus. BMC Infect. Dis. 2015, 15, 492. [CrossRef] [PubMed]

3. Musso, D.; Gubler, D.J. Zika virus. Clin. Microbiol. Rev. 2016, 29, 487-524. [CrossRef] [PubMed] 
4. Saiz, J.C.; Vazquez-Calvo, A.; Blazquez, A.B.; Merino-Ramos, T.; Escribano-Romero, E.; Martin-Acebes, M.A. Zika virus: The latest newcomer. Front. Microbiol. 2016, 7, 496. [CrossRef] [PubMed]

5. Kuno, G.; Chang, G.J. Full-length sequencing and genomic characterization of bagaza, kedougou, and Zika viruses. Arch. Virol. 2007, 152, 687-696. [CrossRef] [PubMed]

6. Dick, G.W.; Kitchen, S.F.; Haddow, A.J. Zika virus. I. Isolations and serological specificity. Trans. R. Soc. Trop. Med. Hyg. 1952, 46, 509-520. [CrossRef]

7. Duffy, M.R.; Chen, T.H.; Hancock, W.T.; Powers, A.M.; Kool, J.L.; Lanciotti, R.S.; Pretrick, M.; Marfel, M.; Holzbauer, S.; Dubray, C.; et al. Zika virus outbreak on yap island, federated states of micronesia. N. Engl. J. Med. 2009, 360, 2536-2543. [CrossRef] [PubMed]

8. Blazquez, A.B.; Saiz, J.C. Neurological manifestations of Zika virus infection. World J. Virol. 2016, 5, 135-143. [CrossRef] [PubMed]

9. WHO. The History of Zika Virus. Available online: http://www.who.int/emergencies/zika-virus/history/en/ (accessed on 17 July 2018).

10. Gourinat, A.C.; O'Connor, O.; Calvez, E.; Goarant, C.; Dupont-Rouzeyrol, M. Detection of Zika virus in urine. Emerg. Infect. Dis. 2015, 21, 84-86. [CrossRef] [PubMed]

11. Coffey, L.L.; Pesavento, P.A.; Keesler, R.I.; Singapuri, A.; Watanabe, J.; Watanabe, R.; Yee, J.; Bliss-Moreau, E.; Cruzen, C.; Christe, K.L.; et al. Zika virus tissue and blood compartmentalization in acute infection of rhesus macaques. PLoS ONE 2017, 12, e0171148. [CrossRef] [PubMed]

12. Miner, J.J.; Diamond, M.S. Zika virus pathogenesis and tissue tropism. Cell Host Microbe 2017, 21, 134-142. [CrossRef] [PubMed]

13. Govero, J.; Esakky, P.; Scheaffer, S.M.; Fernandez, E.; Drury, A.; Platt, D.J.; Gorman, M.J.; Richner, J.M.; Caine, E.A.; Salazar, V.; et al. Zika virus infection damages the testes in mice. Nature 2016, 540, 438-442. [CrossRef] [PubMed]

14. Hirsch, A.J.; Smith, J.L.; Haese, N.N.; Broeckel, R.M.; Parkins, C.J.; Kreklywich, C.; DeFilippis, V.R.; Denton, M.; Smith, P.P.; Messer, W.B.; et al. Zika virus infection of rhesus macaques leads to viral persistence in multiple tissues. PLoS Pathog. 2017, 13, e1006219. [CrossRef] [PubMed]

15. Saiz, J.C.; Martin-Acebes, M.A.; Bueno-Mari, R.; Salomon, O.D.; Villamil-Jimenez, L.C.; Heukelbach, J.; Alencar, C.H.; Armstrong, P.K.; Ortiga-Carvalho, T.M.; Mendez-Otero, R.; et al. Zika virus: What have we learnt since the start of the recent epidemic? Front. Microbiol. 2017, 8, 1554. [CrossRef] [PubMed]

16. WHO. Who Vaccine Pipeline Tracker. Available online: http://www.who.int/immunization/research/ vaccine_pipeline_tracker_spreadsheet/en/ (accessed on 17 July 2018).

17. Menendez-Arias, L.; Richman, D.D. Editorial overview: Antivirals and resistance: Advances and challenges ahead. Curr. Opin. Virol. 2014, 8, iv-vii. [CrossRef] [PubMed]

18. Saiz, J.C.; Martin-Acebes, M.A. The race to find antivirals for Zika virus. Antimicrob. Agents Chemother. 2017, 61. [CrossRef] [PubMed]

19. Khandia, R.; Munjal, A.; Dhama, K. Consequences of Zika virus infection during fetal stage and pregnancy safe drugs: An update. Int. J. Pharmacol. 2017, 13, 370-377.

20. Munjal, A.; Khandia, R.; Dhama, K.; Sachan, S.; Karthik, K.; Tiwari, R.; Malik, Y.S.; Kumar, D.; Singh, R.K.; Iqbal, H.M.N.; et al. Advances in developing therapies to combat Zika virus: Current knowledge and future perspectives. Front. Microbiol. 2017, 8, 1469. [CrossRef] [PubMed]

21. Lei, J.; Hansen, G.; Nitsche, C.; Klein, C.D.; Zhang, L.; Hilgenfeld, R. Crystal structure of Zika virus NS2B-NS3 protease in complex with a boronate inhibitor. Science 2016, 353, 503-505. [CrossRef] [PubMed]

22. Jain, R.; Coloma, J.; Garcia-Sastre, A.; Aggarwal, A.K. Structure of the NS3 helicase from Zika virus. Nat. Struct. Mol. Biol. 2016, 23, 752-754. [CrossRef] [PubMed]

23. Zhang, Z.; Li, Y.; Loh, Y.R.; Phoo, W.W.; Hung, A.W.; Kang, C.; Luo, D. Crystal structure of unlinked NS2B-NS3 protease from Zika virus. Science 2016, 354, 1597-1600. [CrossRef] [PubMed]

24. Godoy, A.S.; Lima, G.M.; Oliveira, K.I.; Torres, N.U.; Maluf, F.V.; Guido, R.V.; Oliva, G. Crystal structure of Zika virus NS5 RNA-dependent RNA polymerase. Nat. Commun. 2017, 8, 14764. [CrossRef] [PubMed]

25. Coloma, J.; Jain, R.; Rajashankar, K.R.; Garcia-Sastre, A.; Aggarwal, A.K. Structures of NS5 methyltransferase from Zika virus. Cell. Rep. 2016, 16, 3097-3102. [CrossRef] [PubMed]

26. Duan, W.; Song, H.; Wang, H.; Chai, Y.; Su, C.; Qi, J.; Shi, Y.; Gao, G.F. The crystal structure of Zika virus NS5 reveals conserved drug targets. EMBO J. 2017, 36, 919-933. [CrossRef] [PubMed] 
27. Wang, B.; Tan, X.F.; Thurmond, S.; Zhang, Z.M.; Lin, A.; Hai, R.; Song, J. The structure of Zika virus NS5 reveals a conserved domain conformation. Nat. Commun. 2017, 8, 14763. [CrossRef] [PubMed]

28. Zhao, B.; Yi, G.; Du, F.; Chuang, Y.C.; Vaughan, R.C.; Sankaran, B.; Kao, C.C.; Li, P. Structure and function of the Zika virus full-length NS5 protein. Nat. Commun. 2017, 8, 14762. [CrossRef] [PubMed]

29. Phoo, W.W.; Li, Y.; Zhang, Z.; Lee, M.Y.; Loh, Y.R.; Tan, Y.B.; Ng, E.Y.; Lescar, J.; Kang, C.; Luo, D. Structure of the NS2B-NS3 protease from Zika virus after self-cleavage. Nat. Commun. 2016, 7, 13410. [CrossRef] [PubMed]

30. Li, Y.; Zhang, Z.; Phoo, W.W.; Loh, Y.R.; Wang, W.; Liu, S.; Chen, M.W.; Hung, A.W.; Keller, T.H.; Luo, D.; et al. Structural dynamics of Zika virus NS2b-NS3 protease binding to dipeptide inhibitors. Structure 2017, 25, 1242-1250.e3. [CrossRef] [PubMed]

31. Li, Y.; Phoo, W.W.; Loh, Y.R.; Zhang, Z.; Ng, E.Y.; Wang, W.; Keller, T.H.; Luo, D.; Kang, C. Structural characterization of the linked NS2b-NS3 protease of Zika virus. FEBS Lett. 2017, 591, 2338-2347. [CrossRef] [PubMed]

32. Li, Y.; Zhang, Z.; Phoo, W.W.; Loh, Y.R.; Li, R.; Yang, H.Y.; Jansson, A.E.; Hill, J.; Keller, T.H.; Nacro, K.; et al. Structural insights into the inhibition of Zika virus NS2B-NS3 protease by a small-molecule inhibitor. Structure 2018, 26, 555-564.e3. [CrossRef] [PubMed]

33. Shang, Z.; Song, H.; Shi, Y.; Qi, J.; Gao, G.F. Crystal structure of the capsid protein from Zika virus. J. Mol. Biol. 2018, 430, 948-962. [CrossRef] [PubMed]

34. Song, H.; Qi, J.; Haywood, J.; Shi, Y.; Gao, G.F. Zika virus NS1 structure reveals diversity of electrostatic surfaces among flaviviruses. Nat. Struct. Mol. Biol. 2016, 23, 456-458. [CrossRef] [PubMed]

35. Xu, X.; Song, H.; Qi, J.; Liu, Y.; Wang, H.; Su, C.; Shi, Y.; Gao, G.F. Contribution of intertwined loop to membrane association revealed by Zika virus full-length NS1 structure. EMBO J. 2016, 35, 2170-2178. [CrossRef] [PubMed]

36. Kostyuchenko, V.A.; Lim, E.X.; Zhang, S.; Fibriansah, G.; Ng, T.S.; Ooi, J.S.; Shi, J.; Lok, S.M. Structure of the thermally stable Zika virus. Nature 2016, 533, 425-428. [CrossRef] [PubMed]

37. Dai, L.; Song, J.; Lu, X.; Deng, Y.Q.; Musyoki, A.M.; Cheng, H.; Zhang, Y.; Yuan, Y.; Song, H.; Haywood, J.; et al. Structures of the Zika virus envelope protein and its complex with a flavivirus broadly protective antibody. Cell Host Microbe 2016, 19, 696-704. [CrossRef] [PubMed]

38. Prasad, V.M.; Miller, A.S.; Klose, T.; Sirohi, D.; Buda, G.; Jiang, W.; Kuhn, R.J.; Rossmann, M.G. Structure of the immature Zika virus at 9 A resolution. Nat. Struct. Mol. Biol. 2017, 24, 184-186. [CrossRef] [PubMed]

39. Vazquez-Calvo, A.; Jimenez de Oya, N.; Martin-Acebes, M.A.; Garcia-Moruno, E.; Saiz, J.C. Antiviral properties of the natural polyphenols delphinidin and epigallocatechin gallate against the flaviviruses West Nile virus, Zika virus, and dengue virus. Front. Microbiol. 2017, 8, 1314. [CrossRef] [PubMed]

40. Wang, S.; Hong, S.; Deng, Y.Q.; Ye, Q.; Zhao, L.Z.; Zhang, F.C.; Qin, C.F.; Xu, Z. Transfer of convalescent serum to pregnant mice prevents Zika virus infection and microcephaly in offspring. Cell Res. 2016, 27, 158-160. [CrossRef] [PubMed]

41. Sapparapu, G.; Fernandez, E.; Kose, N.; Bin, C.; Fox, J.M.; Bombardi, R.G.; Zhao, H.; Nelson, C.A.; Bryan, A.L.; Barnes, T.; et al. Neutralizing human antibodies prevent Zika virus replication and fetal disease in mice. Nature 2016, 540, 443-447. [CrossRef] [PubMed]

42. Stettler, K.; Beltramello, M.; Espinosa, D.A.; Graham, V.; Cassotta, A.; Bianchi, S.; Vanzetta, F.; Minola, A.; Jaconi, S.; Mele, F.; et al. Specificity, cross-reactivity, and function of antibodies elicited by Zika virus infection. Science 2016, 353, 823-826. [CrossRef] [PubMed]

43. Wang, J.; Bardelli, M.; Espinosa, D.A.; Pedotti, M.; Ng, T.S.; Bianchi, S.; Simonelli, L.; Lim, E.X.Y.; Foglierini, M.; Zatta, F.; et al. A human bi-specific antibody against Zika virus with high therapeutic potential. Cell 2017, 171, 229-241.e15. [CrossRef] [PubMed]

44. Abbink, P.; Larocca, R.A.; Dejnirattisai, W.; Peterson, R.; Nkolola, J.P.; Borducchi, E.N.; Supasa, P.; Mongkolsapaya, J.; Screaton, G.R.; Barouch, D.H. Therapeutic and protective efficacy of a dengue antibody against zika infection in rhesus monkeys. Nat. Med. 2018, 24, 721-723. [CrossRef] [PubMed]

45. Stein, D.R.; Golden, J.W.; Griffin, B.D.; Warner, B.M.; Ranadheera, C.; Scharikow, L.; Sloan, A.; Frost, K.L.; Kobasa, D.; Booth, S.A.; et al. Human polyclonal antibodies produced in transchromosomal cattle prevent lethal Zika virus infection and testicular atrophy in mice. Antivir. Res. 2017, 146, 164-173. [CrossRef] [PubMed] 
46. Martin-Acebes, M.A.; Saiz, J.C.; Jimenez de Oya, N. Antibody-dependent enhancement and zika: Real threat or phantom menace? Front. Cell. Infect. Microbiol. 2018, 8, 44. [CrossRef] [PubMed]

47. Halstead, S.B. Pathogenic exploitation of Fc activity. In Antibody Fc Linking Adaptive and Innate Immunity; Ackerman, M., Ed.; Academic Press: Cambridge, MA, USA, 2014; pp. 333-350.

48. Fernandez-Garcia, M.D.; Mazzon, M.; Jacobs, M.; Amara, A. Pathogenesis of flavivirus infections: Using and abusing the host cell. Cell Host Microbe 2009, 5, 318-328. [CrossRef] [PubMed]

49. Pastorino, B.; Nougairede, A.; Wurtz, N.; Gould, E.; de Lamballerie, X. Role of host cell factors in flavivirus infection: Implications for pathogenesis and development of antiviral drugs. Antivir. Res. 2010, 87, 281-294. [CrossRef] [PubMed]

50. Boldescu, V.; Behnam, M.A.M.; Vasilakis, N.; Klein, C.D. Broad-spectrum agents for flaviviral infections: Dengue, zika and beyond. Nat. Rev. Drug Discov. 2017, 16, 565-586. [CrossRef] [PubMed]

51. Krishnan, M.N.; Garcia-Blanco, M.A. Targeting host factors to treat West Nile and dengue viral infections. Viruses 2014, 6, 683-708. [CrossRef] [PubMed]

52. Xie, X.; Zou, J.; Shan, C.; Yang, Y.; Kum, D.B.; Dallmeier, K.; Neyts, J.; Shi, P.Y. Zika virus replicons for drug discovery. EBioMedicine 2016, 12, 156-160. [CrossRef] [PubMed]

53. Kummerer, B.M. Establishment and application of flavivirus replicons. Adv. Exp. Med. Biol. 2018, 1062, 165-173. [PubMed]

54. Lee, I.; Bos, S.; Li, G.; Wang, S.; Gadea, G.; Despres, P.; Zhao, R.Y. Probing molecular insights into Zika virus (-)host interactions. Viruses 2018, 10, 233. [CrossRef] [PubMed]

55. Retallack, H.; Di Lullo, E.; Arias, C.; Knopp, K.A.; Laurie, M.T.; Sandoval-Espinosa, C.; Mancia Leon, W.R.; Krencik, R.; Ullian, E.M.; Spatazza, J.; et al. Zika virus cell tropism in the developing human brain and inhibition by azithromycin. Proc. Natl. Acad. Sci. USA 2016, 113, 14408-14413. [CrossRef] [PubMed]

56. Wells, M.F.; Salick, M.R.; Wiskow, O.; Ho, D.J.; Worringer, K.A.; Ihry, R.J.; Kommineni, S.; Bilican, B.; Klim, J.R.; Hill, E.J.; et al. Genetic ablation of axl does not protect human neural progenitor cells and cerebral organoids from Zika virus infection. Cell Stem Cell 2016, 19, 703-708. [CrossRef] [PubMed]

57. Meertens, L.; Labeau, A.; Dejarnac, O.; Cipriani, S.; Sinigaglia, L.; Bonnet-Madin, L.; Le Charpentier, T.; Hafirassou, M.L.; Zamborlini, A.; Cao-Lormeau, V.M.; et al. Axl mediates Zika virus entry in human glial cells and modulates innate immune responses. Cell Rep. 2017, 18, 324-333. [CrossRef] [PubMed]

58. Wang, Z.Y.; Wang, Z.; Zhen, Z.D.; Feng, K.H.; Guo, J.; Gao, N.; Fan, D.Y.; Han, D.S.; Wang, P.G.; An, J. Axl is not an indispensable factor for Zika virus infection in mice. J. Gen. Virol. 2017, 98, 2061-2068. [CrossRef] [PubMed]

59. Liu, S.; DeLalio, L.J.; Isakson, B.E.; Wang, T.T. Axl-mediated productive infection of human endothelial cells by Zika virus. Circ. Res. 2016, 119, 1183-1189. [CrossRef] [PubMed]

60. Mounce, B.C.; Cesaro, T.; Carrau, L.; Vallet, T.; Vignuzzi, M. Curcumin inhibits zika and chikungunya virus infection by inhibiting cell binding. Antivir. Res. 2017, 142, 148-157. [CrossRef] [PubMed]

61. Tan, C.W.; Sam, I.C.; Chong, W.L.; Lee, V.S.; Chan, Y.F. Polysulfonate suramin inhibits Zika virus infection. Antivir. Res. 2017, 143, 186-194. [CrossRef] [PubMed]

62. Albulescu, I.C.; Kovacikova, K.; Tas, A.; Snijder, E.J.; van Hemert, M.J. Suramin inhibits Zika virus replication by interfering with virus attachment and release of infectious particles. Antivir. Res. 2017, 143, 230-236. [CrossRef] [PubMed]

63. Stiasny, K.; Fritz, R.; Pangerl, K.; Heinz, F.X. Molecular mechanisms of flavivirus membrane fusion. Amino Acids 2011, 41, 1159-1163. [CrossRef] [PubMed]

64. Vazquez-Calvo, A.; Saiz, J.C.; McCullough, K.C.; Sobrino, F.; Martin-Acebes, M.A. Acid-dependent viral entry. Virus Res. 2012, 167, 125-137. [CrossRef] [PubMed]

65. Rausch, K.; Hackett, B.A.; Weinbren, N.L.; Reeder, S.M.; Sadovsky, Y.; Hunter, C.A.; Schultz, D.C.; Coyne, C.B.; Cherry, S. Screening bioactives reveals nanchangmycin as a broad spectrum antiviral active against Zika virus. Cell Rep. 2017, 18, 804-815. [CrossRef] [PubMed]

66. Martin-Acebes, M.A.; Vazquez-Calvo, A.; Saiz, J.C. Lipids and flaviviruses, present and future perspectives for the control of dengue, zika, and West Nile viruses. Prog. Lipid Res. 2016, 64, 123-137. [CrossRef] [PubMed]

67. Haviernik, J.; Stefanik, M.; Fojtikova, M.; Kali, S.; Tordo, N.; Rudolf, I.; Hubalek, Z.; Eyer, L.; Ruzek, D. Arbidol (umifenovir): A broad-spectrum antiviral drug that inhibits medically important arthropod-borne flaviviruses. Viruses 2018, 10, 184. [CrossRef] [PubMed] 
68. Persaud, M.; Martinez-Lopez, A.; Buffone, C.; Porcelli, S.A.; Diaz-Griffero, F. Infection by Zika viruses requires the transmembrane protein AXL, endocytosis and low pH. Virology 2018, 518, 301-312. [CrossRef] [PubMed]

69. Li, C.; Deng, Y.Q.; Wang, S.; Ma, F.; Aliyari, R.; Huang, X.Y.; Zhang, N.N.; Watanabe, M.; Dong, H.L.; Liu, P.; et al. 25-hydroxycholesterol protects host against Zika virus infection and its associated microcephaly in a mouse model. Immunity 2017, 46, 446-456. [CrossRef] [PubMed]

70. Barrows, N.J.; Campos, R.K.; Powell, S.T.; Prasanth, K.R.; Schott-Lerner, G.; Soto-Acosta, R.; Galarza-Munoz, G.; McGrath, E.L.; Urrabaz-Garza, R.; Gao, J.; et al. A screen of FDA-approved drugs for inhibitors of Zika virus infection. Cell Host Microbe 2016, 20, 259-270. [CrossRef] [PubMed]

71. Kuivanen, S.; Bespalov, M.M.; Nandania, J.; Ianevski, A.; Velagapudi, V.; De Brabander, J.K.; Kainov, D.E.; Vapalahti, O. Obatoclax, saliphenylhalamide and gemcitabine inhibit Zika virus infection in vitro and differentially affect cellular signaling, transcription and metabolism. Antivir. Res. 2017, 139, 117-128. [CrossRef] [PubMed]

72. Varghese, F.S.; Rausalu, K.; Hakanen, M.; Saul, S.; Kummerer, B.M.; Susi, P.; Merits, A.; Ahola, T. Obatoclax inhibits alphavirus membrane fusion by neutralizing the acidic environment of endocytic compartments. Antimicrob. Agents Chemother. 2017, 61. [CrossRef] [PubMed]

73. Adcock, R.S.; Chu, Y.K.; Golden, J.E.; Chung, D.H. Evaluation of anti-Zika virus activities of broad-spectrum antivirals and NIH clinical collection compounds using a cell-based, high-throughput screen assay. Antivir. Res. 2017, 138, 47-56. [CrossRef] [PubMed]

74. Delvecchio, R.; Higa, L.M.; Pezzuto, P.; Valadao, A.L.; Garcez, P.P.; Monteiro, F.L.; Loiola, E.C.; Dias, A.A.; Silva, F.J.; Aliota, M.T.; et al. Chloroquine, an endocytosis blocking agent, inhibits Zika virus infection in different cell models. Viruses 2016, 8, 322. [CrossRef] [PubMed]

75. Balasubramanian, A.; Teramoto, T.; Kulkarni, A.A.; Bhattacharjee, A.K.; Padmanabhan, R. Antiviral activities of selected antimalarials against dengue virus type 2 and Zika virus. Antivir. Res. 2017, 137, 141-150. [CrossRef] [PubMed]

76. Cao, B.; Parnell, L.A.; Diamond, M.S.; Mysorekar, I.U. Inhibition of autophagy limits vertical transmission of Zika virus in pregnant mice. J. Exp. Med. 2017, 214, 2303-2313. [CrossRef] [PubMed]

77. Li, C.; Zhu, X.; Ji, X.; Quanquin, N.; Deng, Y.Q.; Tian, M.; Aliyari, R.; Zuo, X.; Yuan, L.; Afridi, S.K.; et al. Chloroquine, a FDA-approved drug, prevents Zika virus infection and its associated congenital microcephaly in mice. EBioMedicine 2017, 24, 189-194. [CrossRef] [PubMed]

78. Shiryaev, S.A.; Mesci, P.; Pinto, A.; Fernandes, I.; Sheets, N.; Shresta, S.; Farhy, C.; Huang, C.T.; Strongin, A.Y.; Muotri, A.R.; et al. Repurposing of the anti-malaria drug chloroquine for Zika virus treatment and prophylaxis. Sci. Rep. 2017, 7, 15771. [CrossRef] [PubMed]

79. Barbosa-Lima, G.; da Silveira Pinto, L.S.; Kaiser, C.R.; Wardell, J.L.; De Freitas, C.S.; Vieira, Y.R.; Marttorelli, A.; Cerbino Neto, J.; Bozza, P.T.; Wardell, S.; et al. N-(2-(arylmethylimino)ethyl)-7-chloroquinolin-4-amine derivatives, synthesized by thermal and ultrasonic means, are endowed with anti-Zika virus activity. Eur. J. Med. Chem. 2017, 127, 434-441. [CrossRef] [PubMed]

80. Barbosa-Lima, G.; Moraes, A.M.; Araujo, A.D.S.; da Silva, E.T.; de Freitas, C.S.; Vieira, Y.R.; Marttorelli, A.; Neto, J.C.; Bozza, P.T.; de Souza, M.V.N.; et al. 2,8-bis(trifluoromethyl)quinoline analogs show improved anti-Zika virus activity, compared to mefloquine. Eur. J. Med. Chem. 2017, 127, 334-340. [CrossRef] [PubMed]

81. Han, Y.; Mesplede, T.; Xu, H.; Quan, Y.; Wainberg, M.A. The antimalarial drug amodiaquine possesses anti-Zika virus activities. J. Med. Virol. 2018, 90, 796-802. [CrossRef] [PubMed]

82. Xu, M.; Lee, E.M.; Wen, Z.; Cheng, Y.; Huang, W.K.; Qian, X.; Tcw, J.; Kouznetsova, J.; Ogden, S.C.; Hammack, C.; et al. Identification of small-molecule inhibitors of Zika virus infection and induced neural cell death via a drug repurposing screen. Nat. Med. 2016, 22, 1101-1107. [CrossRef] [PubMed]

83. Cairns, D.M.; Boorgu, D.; Levin, M.; Kaplan, D.L. Niclosamide rescues microcephaly in a humanized in vivo model of zika infection using human induced neural stem cells. Biol. Open 2018, 7. [CrossRef] [PubMed]

84. Wang, H.; Li, Z.; Niu, J.; Xu, Y.; Ma, L.; Lu, A.; Wang, X.; Qian, Z.; Huang, Z.; Jin, X.; et al. Antiviral effects of ferric ammonium citrate. Cell Discov. 2018, 4, 14. [CrossRef] [PubMed]

85. Elgner, F.; Sabino, C.; Basic, M.; Ploen, D.; Grunweller, A.; Hildt, E. Inhibition of Zika virus replication by silvestrol. Viruses 2018, 10, 149. [CrossRef] [PubMed]

86. Pitts, J.D.; Li, P.C.; de Wispelaere, M.; Yang, P.L. Antiviral activity of N-(4-hydroxyphenyl) retinamide (4-HPR) against Zika virus. Antivir. Res. 2017, 147, 124-130. [CrossRef] [PubMed] 
87. Mounce, B.C.; Poirier, E.Z.; Passoni, G.; Simon-Loriere, E.; Cesaro, T.; Prot, M.; Stapleford, K.A.; Moratorio, G.; Sakuntabhai, A.; Levraud, J.P.; et al. Interferon-induced spermidine-spermine acetyltransferase and polyamine depletion restrict zika and chikungunya viruses. Cell Host Microbe 2016, 20, 167-177. [CrossRef] [PubMed]

88. Mounce, B.C.; Cesaro, T.; Moratorio, G.; Hooikaas, P.J.; Yakovleva, A.; Werneke, S.W.; Smith, E.C.; Poirier, E.Z.; Simon-Loriere, E.; Prot, M.; et al. Inhibition of polyamine biosynthesis is a broad-spectrum strategy against rna viruses. J. Virol. 2016, 90, 9683-9692. [CrossRef] [PubMed]

89. Mukhopadhyay, S.; Kuhn, R.J.; Rossmann, M.G. A structural perspective of the flavivirus life cycle. Nat. Rev. Microbiol. 2005, 3, 13-22. [CrossRef] [PubMed]

90. Roby, J.A.; Setoh, Y.X.; Hall, R.A.; Khromykh, A.A. Post-translational regulation and modifications of flavivirus structural proteins. J. Gen. Virol. 2015, 96, 1551-1569. [CrossRef] [PubMed]

91. Puschnik, A.S.; Marceau, C.D.; Ooi, Y.S.; Majzoub, K.; Rinis, N.; Contessa, J.N.; Carette, J.E. A small-molecule oligosaccharyltransferase inhibitor with pan-flaviviral activity. Cell Rep. 2017, 21, 3032-3039. [CrossRef] [PubMed]

92. Zhang, R.; Miner, J.J.; Gorman, M.J.; Rausch, K.; Ramage, H.; White, J.P.; Zuiani, A.; Zhang, P.; Fernandez, E.; Zhang, Q.; et al. A CRISPR screen defines a signal peptide processing pathway required by flaviviruses. Nature 2016, 535, 164-168. [CrossRef] [PubMed]

93. Estoppey, D.; Lee, C.M.; Janoschke, M.; Lee, B.H.; Wan, K.F.; Dong, H.; Mathys, P.; Filipuzzi, I.; Schuhmann, T.; Riedl, R.; et al. The natural product cavinafungin selectively interferes with zika and dengue virus replication by inhibition of the host signal peptidase. Cell Rep. 2017, 19, 451-460. [CrossRef] [PubMed]

94. Cao, R.Y.; Xu, Y.F.; Zhang, T.H.; Yang, J.J.; Yuan, Y.; Hao, P.; Shi, Y.; Zhong, J.; Zhong, W. Pediatric drug nitazoxanide: A potential choice for control of zika. Open Forum Infect. Dis. 2017, 4, ofx009. [CrossRef] [PubMed]

95. Raekiansyah, M.; Mori, M.; Nonaka, K.; Agoh, M.; Shiomi, K.; Matsumoto, A.; Morita, K. Identification of novel antiviral of fungus-derived brefeldin A against dengue viruses. Trop Med. Health 2017, 45, 32. [CrossRef] [PubMed]

96. Yang, S.; Xu, M.; Lee, E.M.; Gorshkov, K.; Shiryaev, S.A.; He, S.; Sun, W.; Cheng, Y.S.; Hu, X.; Tharappel, A.M.; et al. Emetine inhibits Zika and Ebola virus infections through two molecular mechanisms: Inhibiting viral replication and decreasing viral entry. Cell Discov 2018, 4, 31. [CrossRef] [PubMed]

97. Tang, H.; Hammack, C.; Ogden, S.C.; Wen, Z.; Qian, X.; Li, Y.; Yao, B.; Shin, J.; Zhang, F.; Lee, E.M.; et al. Zika virus infects human cortical neural progenitors and attenuates their growth. Cell Stem Cell 2016, 18, 587-590. [CrossRef] [PubMed]

98. Leonardi, W.; Zilbermintz, L.; Cheng, L.W.; Zozaya, J.; Tran, S.H.; Elliott, J.H.; Polukhina, K.; Manasherob, R.; Li, A.; Chi, X.; et al. Bithionol blocks pathogenicity of bacterial toxins, ricin, and Zika virus. Sci. Rep. 2016, 6, 34475. [CrossRef] [PubMed]

99. Villareal, V.A.; Rodgers, M.A.; Costello, D.A.; Yang, P.L. Targeting host lipid synthesis and metabolism to inhibit dengue and hepatitis c viruses. Antivir. Res. 2015, 124, 110-121. [CrossRef] [PubMed]

100. Garavito, R.M.; Mulichak, A.M. The structure of mammalian cyclooxygenases. Annu. Rev. Biophys. Biomol. Struct. 2003, 32, 183-206. [CrossRef] [PubMed]

101. Opie, L.H. Present status of statin therapy. Trends Cardiovasc. Med. 2015, 25, 216-225. [CrossRef] [PubMed]

102. Merino-Ramos, T.; Vazquez-Calvo, A.; Casas, J.; Sobrino, F.; Saiz, J.C.; Martin-Acebes, M.A. Modification of the host cell lipid metabolism induced by hypolipidemic drugs targeting the acetyl coenzyme a carboxylase impairs West Nile virus replication. Antimicrob. Agents Chemother. 2015, 60, 307-315. [CrossRef] [PubMed]

103. Heaton, N.S.; Perera, R.; Berger, K.L.; Khadka, S.; Lacount, D.J.; Kuhn, R.J.; Randall, G. Dengue virus nonstructural protein 3 redistributes fatty acid synthase to sites of viral replication and increases cellular fatty acid synthesis. Proc. Natl. Acad. Sci. USA 2010, 107, 17345-17350. [CrossRef] [PubMed]

104. Martin-Acebes, M.A.; Blazquez, A.B.; Jimenez de Oya, N.; Escribano-Romero, E.; Saiz, J.C. West nile virus replication requires fatty acid synthesis but is independent on phosphatidylinositol-4-phosphate lipids. PLoS ONE 2011, 6, e24970. [CrossRef] [PubMed]

105. Perera, R.; Riley, C.; Isaac, G.; Hopf-Jannasch, A.S.; Moore, R.J.; Weitz, K.W.; Pasa-Tolic, L.; Metz, T.O.; Adamec, J.; Kuhn, R.J. Dengue virus infection perturbs lipid homeostasis in infected mosquito cells. PLoS Pathog. 2012, 8, e1002584. [CrossRef] [PubMed] 
106. Merino-Ramos, T.; Jimenez de Oya, N.; Saiz, J.C.; Martin-Acebes, M.A. Antiviral activity of nordihydroguaiaretic acid and its derivative tetra-O-methyl nordihydroguaiaretic acid against West Nile virus and Zika virus. Antimicrob. Agents Chemother. 2017, 61. [CrossRef] [PubMed]

107. Pascoalino, B.S.; Courtemanche, G.; Cordeiro, M.T.; Gil, L.H.; Freitas-Junior, L. Zika antiviral chemotherapy: Identification of drugs and promising starting points for drug discovery from an FDA-approved library. F1000Research 2016, 5, 2523. [CrossRef] [PubMed]

108. Sarkey, J.P.; Richards, M.P.; Stubbs, E.B., Jr. Lovastatin attenuates nerve injury in an animal model of guillain-barre syndrome. J. Neurochem. 2007, 100, 1265-1277. [CrossRef] [PubMed]

109. Wichit, S.; Hamel, R.; Bernard, E.; Talignani, L.; Diop, F.; Ferraris, P.; Liegeois, F.; Ekchariyawat, P.; Luplertlop, N.; Surasombatpattana, P.; et al. Imipramine inhibits chikungunya virus replication in human skin fibroblasts through interference with intracellular cholesterol trafficking. Sci. Rep. 2017, 7, 3145. [CrossRef] [PubMed]

110. Huang, Y.; Li, Y.; Zhang, H.; Zhao, R.; Jing, R.; Xu, Y.; He, M.; Peer, J.; Kim, Y.C.; Luo, J.; et al. Zika virus propagation and release in human fetal astrocytes can be suppressed by neutral sphingomyelinase-2 inhibitor GW4869. Cell Discov. 2018, 4, 19. [CrossRef] [PubMed]

111. Martin-Acebes, M.A.; Merino-Ramos, T.; Blazquez, A.B.; Casas, J.; Escribano-Romero, E.; Sobrino, F.; Saiz, J.C. The composition of West Nile virus lipid envelope unveils a role of sphingolipid metabolism in flavivirus biogenesis. J. Virol. 2014, 88, 12041-12054. [CrossRef] [PubMed]

112. Jimenez de Oya, N.; Blazquez, A.B.; Casas, J.; Saiz, J.C.; Martin-Acebes, M.A. Direct activation of adenosine monophosphate-activated protein kinase (AMPK) by PF-06409577 inhibits flavivirus infection through modification of host cell lipid metabolism. Antimicrob. Agents Chemother. 2018, 62. [CrossRef] [PubMed]

113. Cheng, F.; Ramos da Silva, S.; Huang, I.C.; Jung, J.U.; Gao, S.J. Suppression of Zika virus infection and replication in endothelial cells and astrocytes by PKA inhibitor PKI 14-22. J. Virol. 2018, 92. [CrossRef] [PubMed]

114. Grant, A.; Ponia, S.S.; Tripathi, S.; Balasubramaniam, V.; Miorin, L.; Sourisseau, M.; Schwarz, M.C.; Sanchez-Seco, M.P.; Evans, M.J.; Best, S.M.; et al. Zika virus targets human STAT2 to inhibit type I interferon signaling. Cell Host Microbe 2016, 19, 882-890. [CrossRef] [PubMed]

115. Snell, N.J. Ribavirin-Current status of a broad spectrum antiviral agent. Expert Opin. Pharmacother. 2001, 2, 1317-1324. [CrossRef] [PubMed]

116. Markland, W.; McQuaid, T.J.; Jain, J.; Kwong, A.D. Broad-spectrum antiviral activity of the imp dehydrogenase inhibitor VX-497: A comparison with ribavirin and demonstration of antiviral additivity with alpha interferon. Antimicrob. Agents Chemother. 2000, 44, 859-866. [CrossRef] [PubMed]

117. Crotty, S.; Cameron, C.E.; Andino, R. Rna virus error catastrophe: Direct molecular test by using ribavirin. Proc. Natl. Acad. Sci. USA 2001, 98, 6895-6900. [CrossRef] [PubMed]

118. Ortega-Prieto, A.M.; Sheldon, J.; Grande-Perez, A.; Tejero, H.; Gregori, J.; Quer, J.; Esteban, J.I.; Domingo, E.; Perales, C. Extinction of hepatitis c virus by ribavirin in hepatoma cells involves lethal mutagenesis. PLoS ONE 2013, 8, e71039. [CrossRef] [PubMed]

119. Julander, J.G.; Siddharthan, V.; Evans, J.; Taylor, R.; Tolbert, K.; Apuli, C.; Stewart, J.; Collins, P.; Gebre, M.; Neilson, S.; et al. Efficacy of the broad-spectrum antiviral compound BCX4430 against Zika virus in cell culture and in a mouse model. Antivir. Res. 2017, 137, 14-22. [CrossRef] [PubMed]

120. Baz, M.; Goyette, N.; Griffin, B.D.; Kobinger, G.P.; Boivin, G. In vitro susceptibility of geographically and temporally distinct Zika viruses to favipiravir and ribavirin. Antivir. Ther. 2017, 22, 613-618. [CrossRef] [PubMed]

121. Kamiyama, N.; Soma, R.; Hidano, S.; Watanabe, K.; Umekita, H.; Fukuda, C.; Noguchi, K.; Gendo, Y.; Ozaki, T.; Sonoda, A.; et al. Ribavirin inhibits Zika virus (zikv) replication in vitro and suppresses viremia in zikv-infected stat1-deficient mice. Antivir. Res. 2017, 146, 1-11. [CrossRef] [PubMed]

122. Kim, J.A.; Seong, R.K.; Kumar, M.; Shin, O.S. Favipiravir and ribavirin inhibit replication of Asian and African strains of Zika virus in different cell models. Viruses 2018, 10, 72. [CrossRef] [PubMed]

123. Tong, X.; Smith, J.; Bukreyeva, N.; Koma, T.; Manning, J.T.; Kalkeri, R.; Kwong, A.D.; Paessler, S. Merimepodib, an impdh inhibitor, suppresses replication of Zika virus and other emerging viral pathogens. Antivir. Res. 2018, 149, 34-40. [CrossRef] [PubMed] 
124. Goebel, S.; Snyder, B.; Sellati, T.; Saeed, M.; Ptak, R.; Murray, M.; Bostwick, R.; Rayner, J.; Koide, F.; Kalkeri, R. A sensitive virus yield assay for evaluation of antivirals against Zika virus. J. Virol. Methods 2016, 238, 13-20. [CrossRef] [PubMed]

125. Lucas-Hourani, M.; Dauzonne, D.; Jorda, P.; Cousin, G.; Lupan, A.; Helynck, O.; Caignard, G.; Janvier, G.; Andre-Leroux, G.; Khiar, S.; et al. Inhibition of pyrimidine biosynthesis pathway suppresses viral growth through innate immunity. PLoS Pathog. 2013, 9, e1003678. [CrossRef] [PubMed]

126. Chung, D.H.; Golden, J.E.; Adcock, R.S.; Schroeder, C.E.; Chu, Y.K.; Sotsky, J.B.; Cramer, D.E.; Chilton, P.M.; Song, C.; Anantpadma, M.; et al. Discovery of a broad-spectrum antiviral compound that inhibits pyrimidine biosynthesis and establishes a type 1 interferon-independent antiviral state. Antimicrob. Agents Chemother. 2016, 60, 4552-4562. [CrossRef] [PubMed]

127. Zhou, T.; Tan, L.; Cederquist, G.Y.; Fan, Y.; Hartley, B.J.; Mukherjee, S.; Tomishima, M.; Brennand, K.J.; Zhang, Q.; Schwartz, R.E.; et al. High-content screening in HPSC-neural progenitors identifies drug candidates that inhibit Zika virus infection in fetal-like organoids and adult brain. Cell Stem Cell 2017, 21, 274-283.e5. [CrossRef] [PubMed]

128. Cugola, F.R.; Fernandes, I.R.; Russo, F.B.; Freitas, B.C.; Dias, J.L.; Guimaraes, K.P.; Benazzato, C.; Almeida, N.; Pignatari, G.C.; Romero, S.; et al. The Brazilian Zika virus strain causes birth defects in experimental models. Nature 2016, 534, 267-271. [CrossRef] [PubMed]

129. Garcez, P.P.; Loiola, E.C.; Madeiro da Costa, R.; Higa, L.M.; Trindade, P.; Delvecchio, R.; Nascimento, J.M.; Brindeiro, R.; Tanuri, A.; Rehen, S.K. Zika virus impairs growth in human neurospheres and brain organoids. Science 2016, 352, 816-818. [CrossRef] [PubMed]

130. Li, C.; Xu, D.; Ye, Q.; Hong, S.; Jiang, Y.; Liu, X.; Zhang, N.; Shi, L.; Qin, C.F.; Xu, Z. Zika virus disrupts neural progenitor development and leads to microcephaly in mice. Cell Stem Cell 2016, 19, 120-126. [CrossRef] [PubMed]

131. Costa, V.V.; Del Sarto, J.L.; Rocha, R.F.; Silva, F.R.; Doria, J.G.; Olmo, I.G.; Marques, R.E.; Queiroz-Junior, C.M.; Foureaux, G.; Araujo, J.M.S.; et al. N-methyl-D-aspartate (NMDA) receptor blockade prevents neuronal death induced by Zika virus infection. mBio 2017, 8. [CrossRef] [PubMed]

132. Simanjuntak, Y.; Liang, J.J.; Chen, S.Y.; Li, J.K.; Lee, Y.L.; Wu, H.C.; Lin, Y.L. Ebselen alleviates testicular pathology in mice with Zika virus infection and prevents its sexual transmission. PLoS Pathog. 2018, 14, e1006854. [CrossRef] [PubMed]

133. Contreras, D.; Arumugaswami, V. Zika virus infectious cell culture system and the in vitro prophylactic effect of interferons. J. Vis. Exp. 2016. [CrossRef] [PubMed]

134. Bayer, A.; Lennemann, N.J.; Ouyang, Y.; Bramley, J.C.; Morosky, S.; Marques, E.T., Jr.; Cherry, S.; Sadovsky, Y.; Coyne, C.B. Type iii interferons produced by human placental trophoblasts confer protection against Zika virus infection. Cell Host Microbe 2016, 19, 705-712. [CrossRef] [PubMed]

135. Jagger, B.W.; Miner, J.J.; Cao, B.; Arora, N.; Smith, A.M.; Kovacs, A.; Mysorekar, I.U.; Coyne, C.B.; Diamond, M.S. Gestational stage and IFN-lambda signaling regulate ZIKV infection in utero. Cell Host Microbe 2017, 22, 366-376e363. [CrossRef] [PubMed]

136. Savidis, G.; Perreira, J.M.; Portmann, J.M.; Meraner, P.; Guo, Z.; Green, S.; Brass, A.L. The IFITMs inhibit Zika virus replication. Cell Rep. 2016, 15, 2323-2330. [CrossRef] [PubMed]

137. Pryke, K.M.; Abraham, J.; Sali, T.M.; Gall, B.J.; Archer, I.; Liu, A.; Bambina, S.; Baird, J.; Gough, M.; Chakhtoura, M.; et al. A novel agonist of the TRIF pathway induces a cellular state refractory to replication of zika, chikungunya, and dengue viruses. mBio 2017, 8. [CrossRef] [PubMed]

138. Kumar, A.; Hou, S.; Airo, A.M.; Limonta, D.; Mancinelli, V.; Branton, W.; Power, C.; Hobman, T.C. Zika virus inhibits type-I interferon production and downstream signaling. EMBO Rep. 2016, 17, 1766-1775. [CrossRef] [PubMed]

139. Bowen, J.R.; Quicke, K.M.; Maddur, M.S.; O’Neal, J.T.; McDonald, C.E.; Fedorova, N.B.; Puri, V.; Shabman, R.S.; Pulendran, B.; Suthar, M.S. Zika virus antagonizes type I interferon responses during infection of human dendritic cells. PLoS Pathog. 2017, 13, e1006164. [CrossRef] [PubMed]

140. Chen, J.; Yang, Y.F.; Yang, Y.; Zou, P.; He, Y.; Shui, S.L.; Cui, Y.R.; Bai, R.; Liang, Y.J.; Hu, Y.; et al. AXL promotes Zika virus infection in astrocytes by antagonizing type I interferon signalling. Nat. Microbiol. 2018, 3, 302-309. [CrossRef] [PubMed] 
141. Yockey, L.J.; Jurado, K.A.; Arora, N.; Millet, A.; Rakib, T.; Milano, K.M.; Hastings, A.K.; Fikrig, E.; Kong, Y.; Horvath, T.L.; et al. Type I interferons instigate fetal demise after Zika virus infection. Sci. Immunol. $2018,3$. [CrossRef] [PubMed]

142. Smith, J.L.; Jeng, S.; McWeeney, S.K.; Hirsch, A.J. A microRNA screen identifies the Wnt signaling pathway as a regulator of the interferon response during flavivirus infection. J. Virol. 2017, 91. [CrossRef] [PubMed]

143. Arbuckle, J.H.; Gardina, P.J.; Gordon, D.N.; Hickman, H.D.; Yewdell, J.W.; Pierson, T.C.; Myers, T.G.; Kristie, T.M. Inhibitors of the histone methyltransferases EZH2/1 induce a potent antiviral state and suppress infection by diverse viral pathogens. mBio 2017, 8. [CrossRef] [PubMed]

(C) 2018 by the authors. Licensee MDPI, Basel, Switzerland. This article is an open access article distributed under the terms and conditions of the Creative Commons Attribution (CC BY) license (http://creativecommons.org/licenses/by/4.0/). 